\title{
An analysis of the chemistry, mineralogy and texture of waste dolomite powder used to identify its potential application in industry
}

\author{
Agnieszka Gruszecka-Kosowska ${ }^{1}$, Magdalena Wdowin ${ }^{2}$, \\ Tomasz Kosowski ${ }^{3}$, Agnieszka Klimek ${ }^{4}$ \\ ${ }^{1}$ AGH University of Science and Technology, Faculty of Geology, Geophysics and Environmental Protection, Department \\ of Environmental Protection; al. A. Mickiewicza 30,30-059 Krakow, Poland, e-mail:agnieszka.gruszecka@agh.edu.pl \\ ${ }^{2}$ Mineral and Energy Economy Research Institute of the Polish Academy of Sciences; ul. J. Wybickiego 7, 31-261 Krakow, Poland \\ ${ }^{3}$ Research and Development Center for Mining of Chemical Raw Materials CHEMKOP Ltd.; \\ ul. J. Wybickiego 7, 31-261 Krakow, Poland \\ ${ }^{4}$ AGH University of Science and Technology, Faculty of Geology, Geophysics and Environmental Protection, Department \\ of Mineralogy, Petrography and Geochemistry; al. A. Mickiewicza 30, 30-059 Krakow, Poland
}

(C) 2015 Authors. This is an open access publication, which can be used, distributed and reproduced in any medium according to the Creative Commons CC-BY 4.0 License requiring that the original work has been properly cited.

Received: 19 November 2015; accepted: 18 February 2016

\begin{abstract}
In this work, characterization of dolomite powder was carried out in order to specify possible industrial applications. After the technological use of dolomite aggregates, the remaining fine powder becomes a waste. Raw and calcined powder samples were subject to mineralogical, textural and chemical studies involving leaching tests. The results of the calcination process indicate that the carbonate minerals present in the material sample undergo complete decomposition to form oxides. After the calcination, the material is practically non-porous, and its surface area is more than five times lower than that of the raw material. However, due to the high content of calcia in the calcined sample $(\mathrm{CaO}>45 \% \mathrm{wt}$.), the material cannot be used as an additive in cement. The leaching tests showed that the concentration of metals released from the dolomite powder is low enough to classify the material as hazardous waste according to the TCLP test. Moreover, the concentration of metals that can get into the environment does not exceed permissible values as set by Polish law. Thus, it is recommended and justified to carry out detailed tests for the purpose of environmental protection; i.e. wet flue gas desulfurization, heavy metals absorption, and $\mathrm{CO}_{2}$ capture.
\end{abstract}

Keywords: dolomite powder; heavy metals; waste utilization; mineralogical-chemical research; environmental protection

\section{INTRODUCTION}

Natural limestone is used in Poland for economic purposes in significant amounts; particularly in building and road engineering projects. These processes generate large amounts of mineral waste. Slightly coarser fractions of the mineral waste are then reused in other technological processes. Only a few percent of all generated waste dolomite powder is reused; i.e. as a filler in the production of bituminous road-surfaces. Mineral material is still relatively cheap and easy to obtain from deposits, whereas the waste material from technological processes is generally deposited in the landfills. However, it should be noted that the deposits of limestone are limited, 
and considering rational deposit management, we may say that there are areas where the materials of highest quality are not necessary. Environmental protection may serve as an example here, because the used material will be contaminated in the process of remediation anyway. On the other hand, a material that in one type of industry is considered as waste, can be useful in another manufacturing process (Zhang et al. 2008, Disfani et al. 2011, Park \& Chertov 2014). Depending on the type of waste material, the potential ways in which it could be used for economic purposes are as follows: building engineering, where it could be used as an additive in the production of concrete or as a binding material for the production of cement, replacing Portland cement clinker (Kinuthia \& Nidzam 2011, Bilgin et al. 2012, Dell'Orso et al. 2012, Chen et al. 2013, Helios-Rybicka et al. 2013, Romero et al. 2013, Alaibdo et al. 2014); road engineering, where it can be considered as a material for soil stabilization, or to create road surfaces (Poon \& Chan 2006, Engelsen et al. 2012, Galvín et al. 2013); agriculture, where it could be used as a fertilizer or to neutralize soil acidification (Harris \& Lottermoser 2006, Mangwandi \& Tao 2013, Tozsin et al. 2014). Currently, broadly understood environmental protection is also considered to have an economic basis, as environmental standards need to be met. Therefore, mineral resources can be used for purposes such as binding $\mathrm{CO}_{2}$, or heavy metal removal from water or wastewater (Aziz et al. 2008, Pérez-López et al. 2010, Macías et al. 2012, Said et al. 2013).

In Poland, attempts to utilize industrial waste have been carried out for many years (Skarżyńska 1995, Uliasz-Bocheńczyk et al. 2009, Trypuć \& Białowicz 2011, Wdowin \& Gruszecka 2012). However, the results of scientific research alone are not enough. Environmental awareness, as well as the interest of the producer and of the potential customer of such wastes, is also essential.

Thus, in the context of sustainable development and the 3R Principle in rational management of wastes (Reduce - Reuse - Recycle), detailed mineralogical, chemical and textural characteristics of the waste dolomite powder have been studied for potential industrial applications. Therefore, for raw and calcined dolomite powder $\mathrm{XRD}, \mathrm{XRF}$, textural analysis and leaching tests were carried out.

\section{MATERIALS AND METHODS}

\section{Materials}

For the investigation, two types of dolomite powder were used. The first one was a raw dolomite powder coming from dedusting dolomite aggregates, exploited in the dolomite deposit in southern Poland. Dolomite aggregates are given the process of dedusting before they can be used in later technological processes; i.e. in road and civil engineering. These carbonates are Middle Devonian dolomites, documented in Poland as a raw material for road and building engineering. The dolomite is characterized by a large variability of chemical composition, mainly $\mathrm{MgO}, \mathrm{SiO}_{2}$ and $\mathrm{Fe}_{2} \mathrm{O}_{3}$. The changes in chemical composition that are observed in the Devonian dolomites surrounding Dubie are the result of porphyry intrusions impact (Kozłowski 1986). The increased temperature and presence of hydrothermal solutions caused partial dolomitization of primary carbonate minerals. Dolomites from that area are medium-, sometimes coarsely-crystalline, rarely fine-crystalline, usually consolidated and microporous rocks (Lewandowska 1991). Dolomite aggregates are characterized by high quality parameters, and therefore, appeal to a wide range of buyers (Ney 2000, Bąk et al. 2011). The second type of material was the same dolomite powder, but calcined in the temperature of $1450^{\circ} \mathrm{C}$ for 20 minutes. These conditions were suggested by the production technology of clinker cement (Hewlett 1998, Peukert 2000).

\section{Mineralogical analysis}

The mineral composition of raw and calcined dolomitic materials was determined via powder $\mathrm{X}$-ray diffraction methods (XRD), using a PANalytical X'Pert PRO MDP diffractometer with PW 3050 goniometer, $\mathrm{Cu}$ LFF ceramic lamp and bent monochromator from $5^{\circ} 2 \theta$ to $70^{\circ} 2 \theta$. Diffraction data was processed by the software of the Philips X'Pert and ClayLab ver. 1.0. Mineral phases were identified based on the PDF-2 release 2010, formalized by the Joint Committee on Powder Diffraction Standards - ICCD.

\section{Textural analysis}

The textural properties (specific surface area, total pore volume and pore size) were investigated with the ASAP 2020 Micromeritics analyzer. 
Surface characterization was carried out using a low-temperature nitrogen adsorption isotherm, at $-196.15^{\circ} \mathrm{C}$ of liquid nitrogen. Samples were degassed at low pressure, at the temperature of $250^{\circ} \mathrm{C}$ for 6 hours. The time set as an equivalent interval was 30 seconds. The mass of the sample was approximately $2.5 \mathrm{~g}$. Prior to the analysis, samples were degassed under strictly controlled conditions (temperature $250^{\circ} \mathrm{C}$, for $24 \mathrm{~h}$ and reduced pressure $10^{-3} \mathrm{hPa}$ ). The specific surface area was determined based on the BET multilayer adsorption theory (Brunauer et al. 1938), at a $p / p_{0}$ ( $p$ and $p_{0}$ are the equilibrium and saturation pressure of nitrogen, respectively) between 0.06 and 0.3 . The pore volume $\left(V_{p}\right)$ was determined from the adsorbed nitrogen volume at $p / p_{0}=0.98$. Mean diameters of pores $\left(D_{p}\right)$ were calculated according to $D_{p}=4 V_{p} / S_{\mathrm{BET}}$, where $S_{\mathrm{BET}}$ is the BET surface area. The pore volume distribution $\left(R_{p}\right)$ was calculated using a general isotherm equation, based on the combination of a modified Kelvin equation and an average thickness of the adsorbed film.

\section{Particle size analysis}

Granulometric analyses of raw dolomitic powder were performed using a laser particle analyzer Fritsch GmBH Analysette 22, Idar-Oberstein, Germany, equipped with helium-neon laser, optical system, measuring flow cell for suspensions and a dispersing unit.

\section{Chemical analysis}

The chemical composition of samples was determined by the XRF method, with the use of the Philips spectrometer, PW 1404, with an X-ray tube equipped with dual $\mathrm{Cr}-\mathrm{Au}$ anode, with a maximum power of $3 \mathrm{~kW}$, used as the excitation source. The chemical analysis included the determination of: the analytical moisture and the loss on ignition (in the temperature of $815^{\circ} \mathrm{C}$ ) by the gravimetric method, a basic chemical composition $\left(\mathrm{SiO}_{2}, \mathrm{Al}_{2} \mathrm{O}_{3}\right.$, $\mathrm{Fe}_{2} \mathrm{O}_{3}, \mathrm{CaO}, \mathrm{MgO}, \mathrm{Na}_{2} \mathrm{O}, \mathrm{K}_{2} \mathrm{O}, \mathrm{SO}_{3}, \mathrm{TiO}_{2}, \mathrm{P}_{2} \mathrm{O}_{5}$ ) by wavelength dispersive $\mathrm{X}$-ray fluorescence spectrometry, the content of heavy metals $(\mathrm{Cd}, \mathrm{Cr}, \mathrm{Cu}, \mathrm{Ni}$, $\mathrm{Pb}, \mathrm{Hg}, \mathrm{Tl}, \mathrm{Zn}$ ) and metalloids (As, Sb) by ICP-OES.

\section{Leaching tests}

Leaching tests were made in order to determine if there is an impact on the environment caused by potential contamination leakage from the waste material. The first leaching test was performed in accordance with the Polish standard PN-EN 12457:2006. Using distilled water with liquid to solid $(L / S)$ ratio equal to $10: 1$ in the test simulates the most natural environmental conditions (not taking into account the phenomenon of acidification, such as acid rain). The second leaching test was the Toxicity Characteristic Leaching Procedure TCLP (US EPA 1992), using acetic acid or the mixture of acetic acid and sodium hydroxide, depending on the $\mathrm{pH}$ of the tested waste material, where the $L / S$ ratio is equal to $20: 1$. Concentrations of metals in eluates were determined using the ICP-MS apparatus. The TCLP test determines whether a waste is hazardous when the analysed effluent limit value is exceeded (US EPA 2014). It is essential to carry out leaching tests when the commercial use of the waste material is being considered (Gruszecka-Kosowska \& Mikoda 2015). The test also determines the risk of releasing pollutants from waste into the environment triggered by rainwater and infiltrating.

\section{RESULTS AND DISCUSSION}

\section{Mineralogical characteristics}

XRD mineralogical analyses are based on semi-quantitative estimations of individual peaks. The raw waste mainly consisted of carbonate minerals (dolomite - $\mathrm{CaMg}\left(\mathrm{CO}_{3}\right)_{2}$, calcite $\mathrm{CaCO}_{3}$ and ankerite - $\left.\mathrm{Ca} \mathrm{Fe}\left(\mathrm{CO}_{3}\right)_{2}\right)$, while quartz $\left(\mathrm{SiO}_{2}\right)$, feldspars and galena $(\mathrm{PbS})$ were observed in much lower concentrations (Fig. 1). XRD analysis of the calcined powder (Fig. 2) showed that the carbonate minerals were completely converted into oxide forms. After the calcination, larnite $\left(\mathrm{Ca}_{2}\left(\mathrm{SiO}_{4}\right)\right.$, browmillerite $\left(\mathrm{Ca}_{2}(\mathrm{Al}, \mathrm{Fe})_{2} \mathrm{O}_{5}\right)$, periclase $(\mathrm{MgO})$, yeelmite $\left(\mathrm{Ca}_{4} \mathrm{Al}_{6} \mathrm{O}_{12}\left(\mathrm{SO}_{4}\right)\right.$, anatase $\left(\mathrm{TiO}_{2}\right)$ and grossular $\left(\mathrm{Ca}_{3} \mathrm{Al}_{2}\left(\mathrm{SiO}_{4}\right)_{3}\right)$ were observed in the material.

\section{Textural characteristics}

The curve of the pore size distribution (Fig. 3) determined in the range of $1.7-300 \mathrm{~nm}$ of raw waste, were homogeneous - modal (only one maximum is observed i.e. one range of pores is predominant). Pore size variability was in the range of 2-65 nm, with the predominance of pores with a diameter of $10-15 \mathrm{~nm}$, indicating a mesoporous nature of the waste. 


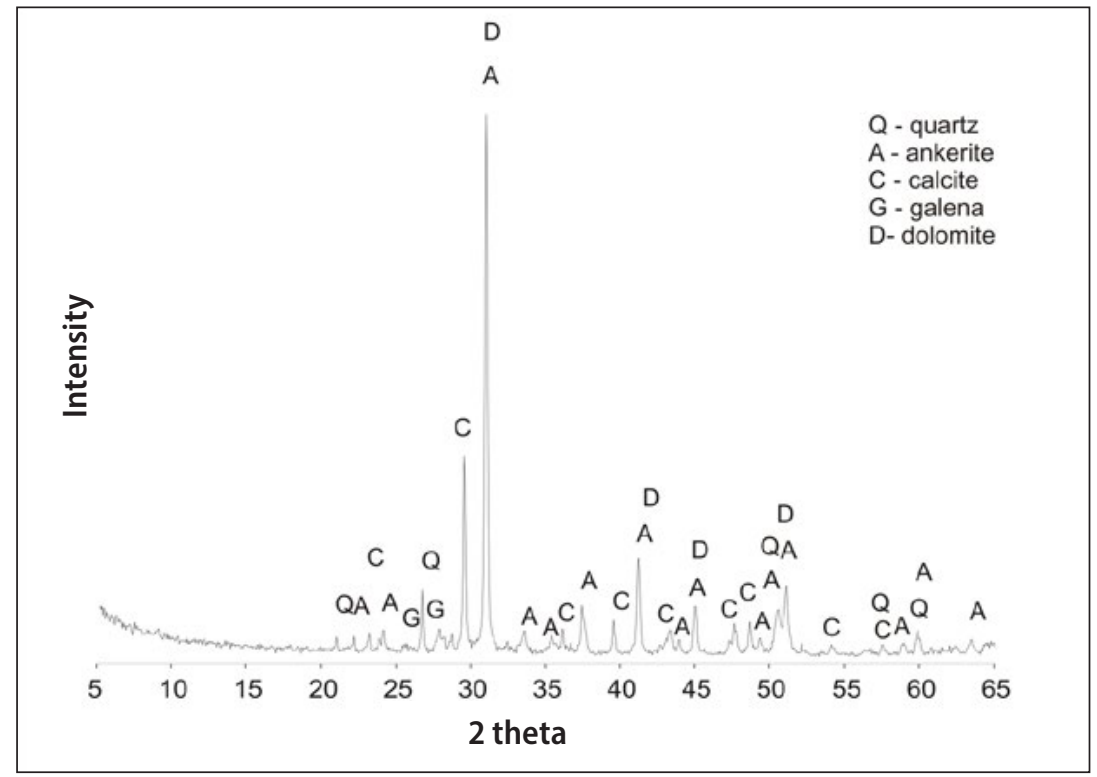

Fig. 1. An XRD diffraction pattern of raw dolomite powder

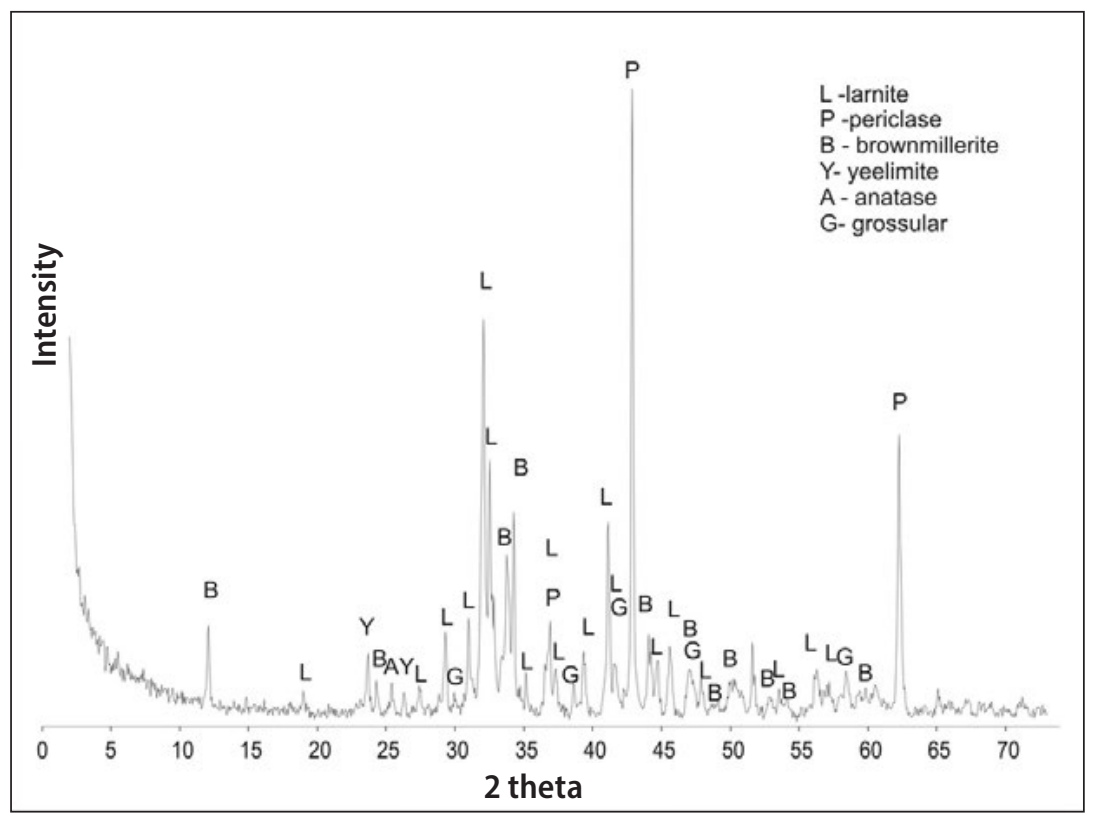

Fig. 2. An XRD diffraction pattern of calcined dolomite powder

The isotherm for the raw waste was characterized by type IV isotherms, according to the IUPAC classification (International Union of Pure and Applied Chemistry), confirming its mesoporous nature without presence of micropores (Fig. 4). The hysteresis loops were defined as a type H3, suggesting a slit-shape pores. The hysteresis loop also indicated capillary condensation in mesopores. According to the classification proposed by de Boer (de Boer 1958), the hysteresis loops could be defined as type $\mathrm{E}$, which corresponded to the most common spherical form of pores, with open ends and significant internal constrictions (Sarbak 2005). The specific surface area of the raw waste was $5.26 \mathrm{~m}^{2} / \mathrm{g}$. It was evident for the calcined sample of waste that the material is of very low porosity. The volume of pores in the range $2-300 \mathrm{~nm}$ was only $0.004 \mathrm{~cm}^{3} / \mathrm{g}$. A negligible amount of pores was also observed, with the adsorption/desorption of isotherms, along with the PSD curve of heterogeneous nature (more than two maxima of pores i.e. PSD curve is multimodal). 


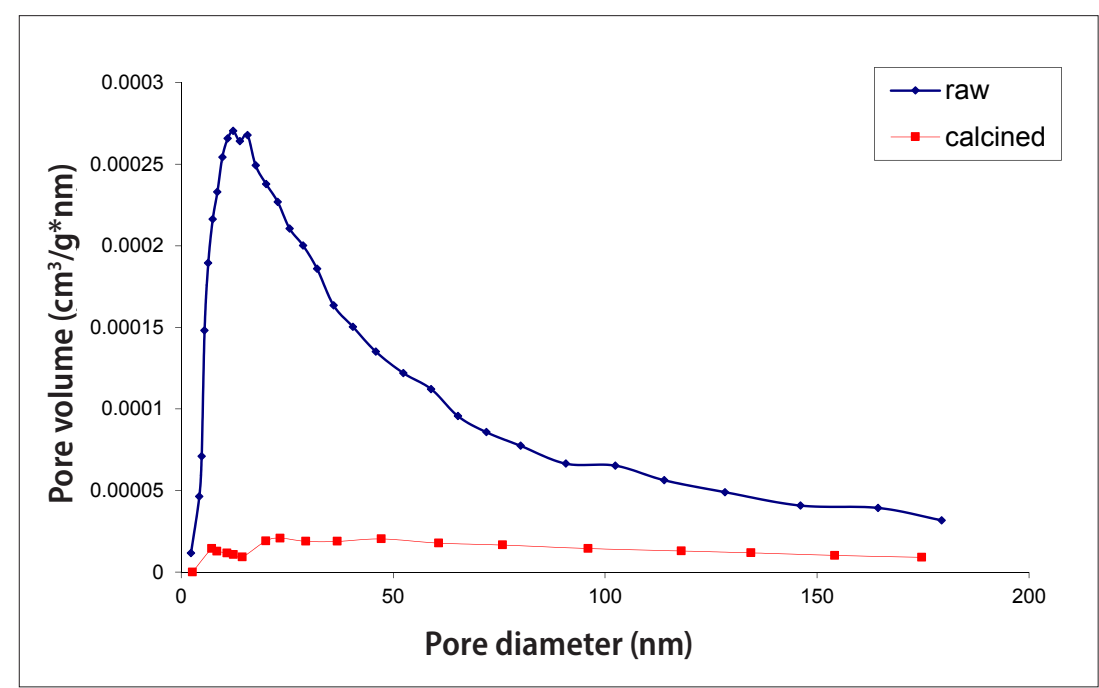

Fig. 3. Pore size distribution of raw and calcined dolomite powder

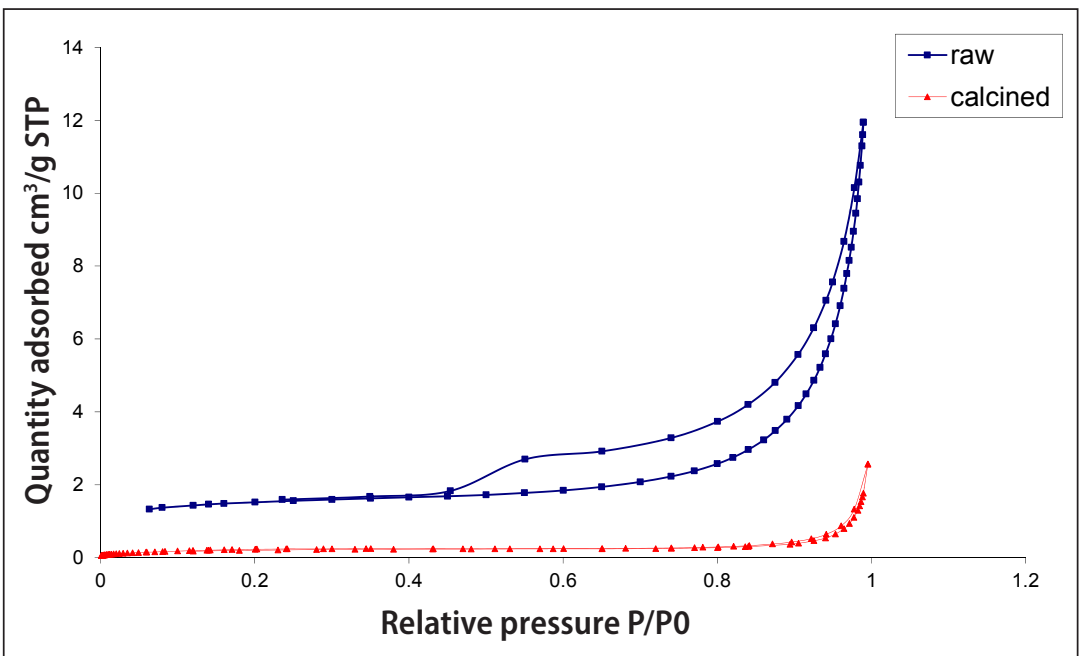

Fig. 4. Adsorption/desorption isotherm of nitrogen for raw and calcined dolomite powder

However, in such low pore volumes, it is assumed that tested calcined materials are nonporous. The BET surface area of the calcined material was more than five times smaller than that of the starting material, measuring at $0.87 \mathrm{~m}^{2} / \mathrm{g}$.

\section{Particle size analysis}

Particle size was determined for the raw dolomite powder. It was in the range of 0.3 to $110 \mu \mathrm{m}$, with the predominant grain size of $20 \mu \mathrm{m}$ (Fig. 5). Particle size was not determined in the calcined dolomite dust sample, due to the fact that the sample was sintered during the calcination. Thus, the sample had to be crushed mechanically, leading to possibly unreliable results of particle size analysis of the calcined dolomite dust.

\section{Chemical characteristic}

The results of chemical analyses for raw and calcined dolomite powder were given in Table 1. The chemical composition comprised primarily calcium, magnesium and silica, which indicated the presence and predominance of carbonate and silica minerals. Iron, aluminum and sulfur were present in similar, but much lower concentrations than mentioned above. Iron is related to the presence of ankerite in raw material, aluminium to some alluvial phase, sulfur to galena. The lowest concentration of elements was observed in the case of sodium, potassium, titanium and phosphorus, which constitute isomorphic substitutions in the minerals. The analysis of the concentrations of heavy metals in the raw dolomite powder sample 
showed a large amount of zinc and lead, which confirmed the presence of sulfide minerals. Arsenic, cadmium, chromium, copper and nickel were observed in lower quantities that constituted isomorphic substitutions in minerals. The lowest concentration was recorded for mercury. The calcination process did not affect the content of the major elements to a great extent. Only the concentration of aluminium increased more than twice. This was related to the sintering of this material in a ceramic pot (during calcination of tested materials the sample sintered with the ceramic pot. As such, some pollution of $\mathrm{Al}$ as well as $\mathrm{Si}$ can also occur in the sample).

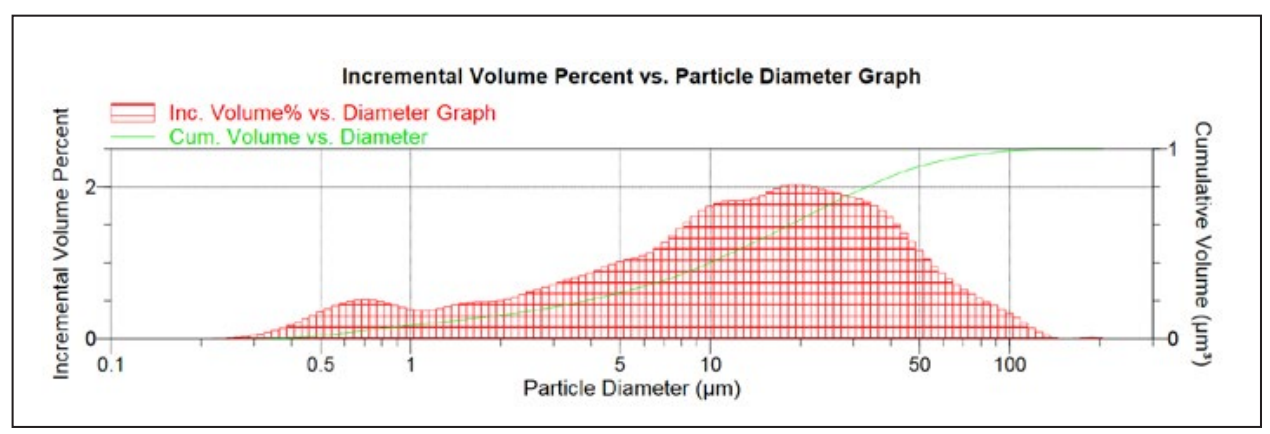

Fig. 5. Distribution of particle size for raw dolomite powder

\section{Table 1}

Chemical characterization of dolomite powder

\begin{tabular}{|c|c|c|c|}
\hline \multirow[b]{2}{*}{ Indication } & \multicolumn{2}{|c|}{ Raw dolomite powder } & \multirow{2}{*}{$\begin{array}{c}\text { Calcined } \\
\text { dolomite powder }\end{array}$} \\
\hline & $\begin{array}{l}\text { concentration after } \\
\text { combustion at } 815^{\circ} \mathrm{C}\end{array}$ & $\begin{array}{c}\text { concentration } \\
\text { before combustion }\end{array}$ & \\
\hline \multicolumn{4}{|c|}{ [\% weight] $(\% \mathrm{~m} / \mathrm{m})$} \\
\hline $\mathrm{SiO}_{2}$ & 15.38 & 10.39 & 16.75 \\
\hline $\mathrm{Al}_{2} \mathrm{O}_{3}$ & 4.29 & 2.90 & 9.84 \\
\hline $\mathrm{Fe}_{2} \mathrm{O}_{3}$ & 4.12 & 2.78 & 4.12 \\
\hline $\mathrm{CaO}$ & 48.36 & 32.66 & 45.61 \\
\hline $\mathrm{MgO}$ & 19.38 & 13.09 & 17.04 \\
\hline $\mathrm{Na}_{2} \mathrm{O}$ & 0.50 & 0.34 & 0.53 \\
\hline $\mathrm{K}_{2} \mathrm{O}$ & 0.60 & 0.41 & 0.49 \\
\hline $\mathrm{SO}_{3}$ & 4.64 & 3.13 & 3.45 \\
\hline $\mathrm{TiO}_{2}$ & 0.18 & 0.12 & 0.19 \\
\hline $\mathrm{P}_{2} \mathrm{O}_{5}$ & 0.22 & 0.15 & 0.27 \\
\hline LOI & - & 32.47 & - \\
\hline Sum & 97.67 & 98.44 & 98.29 \\
\hline \multicolumn{4}{|c|}{$[\mathrm{mg} / \mathrm{kg}](\mathrm{ppm})$} \\
\hline As & \multicolumn{2}{|c|}{75} & 96 \\
\hline $\mathrm{Cd}$ & \multicolumn{2}{|c|}{41} & 12 \\
\hline $\mathrm{Cr}$ & \multicolumn{2}{|c|}{14} & 21 \\
\hline $\mathrm{Cu}$ & \multicolumn{2}{|c|}{13} & 25 \\
\hline $\mathrm{Hg}$ & \multicolumn{2}{|c|}{0,09} & 0,01 \\
\hline $\mathrm{Ni}$ & \multicolumn{2}{|c|}{12} & 16 \\
\hline $\mathrm{Pb}$ & \multicolumn{2}{|c|}{1137} & 536 \\
\hline $\mathrm{Sb}$ & \multicolumn{2}{|c|}{2} & 3 \\
\hline $\mathrm{Zn}$ & \multicolumn{2}{|c|}{4571} & 5564 \\
\hline $\mathrm{Tl}$ & \multicolumn{2}{|c|}{3} & $<3$ \\
\hline
\end{tabular}


Having analysed the mineralogical and chemical results, it was observed that the raw dolomite powder had quite different characteristics from the calcined material. The results of textural analysis demonstrated that the calcination of the raw powder sample caused formation of a practically non-porous material. In addition, the surface area of the raw material was very small and decreased significantly after the calcination process. In addition, as the result of the sintering of dolomite powder, the amount of pores significantly decreased. Moreover, the thermal process changed completely the mineral composition of the powder. The raw material consisted mainly of carbonate minerals, while the calcined material was mainly comprised of oxide minerals.

\section{Leaching tests}

The results of leaching tests performed on raw and calcined dolomite powder samples, as well as, permissible concentrations presented in accordance with the relevant regulations were given in Table 2 . The results of water leaching tests were compared with the values given in the Polish Journal of Law (Rozporzadzenie... 2014). In the case of the TCLP, test values developed by US EPA were used (US EPA 2014). It should be noted that in both tests the amount of metal concentration released from the samples did not exceed the permissible levels. This means that in case of any water leaching, there would be no threat to the environment, such as the infiltration of heavy metals from the raw material into the environment caused by rainwater. The results of the TCLP test indicated that, according to the US EPA regulations, this material cannot be classified as hazardous waste, because the threshold values were not exceeded. It needs to be pointed out that the concentration of $\mathrm{Pb}$ and $\mathrm{Zn}$ in leachates from the leaching tests was insignificant, although the concentration of these metals in the raw material was very high. Dusting, causing very fine material fraction, may pose a threat to the environment. If the dolomite powder were to be used for soil neutralization, there should be no risk of heavy metals contamination from leachates. Moreover, carbonate minerals are easily reactive (mainly in acidic environments), which justifies the need to carry out further research on the usage of the powder as sorbent of metals and other contaminates in wastewaters (Wang et al. 2003, Aziz et al. 2008, Dehghani \& Bridjanian 2010, Mahmoud et al. 2010, Ahmaruzzaman 2011, Xing et al. 2011, Merrikhpour \& Jalali 2012).

Considering the most likely direction of potential further applications of dolomite powder in industry, generally speaking, environmental protection can be identified. Because of the fine fraction, dolomite dust cannot be used as a filler in concrete or road surfaces in very large quantities.

Table 2

Concentrations of selected elements in eluates from the water leaching test and the TCLP test of dolomite powder

\begin{tabular}{|c|c|c|c|c|c|c|}
\hline \multirow{3}{*}{ Metal } & \multicolumn{2}{|c|}{ Water eluate } & \multirow{2}{*}{$\begin{array}{c}\text { Permissible } \\
\text { concentration in } \\
\text { water leaching } \\
\text { eluates }^{*}\end{array}$} & \multicolumn{2}{|c|}{ TCLP eluates } & \multirow[b]{2}{*}{$\begin{array}{c}\text { Permissible } \\
\text { concentration in } \\
\text { TCLP eluates }\end{array}$} \\
\hline & $\begin{array}{c}\text { raw dolomite } \\
\text { powder }\end{array}$ & $\begin{array}{c}\text { calcined } \\
\text { dolomite } \\
\text { powder }\end{array}$ & & $\begin{array}{c}\text { raw } \\
\text { dolomite } \\
\text { powder }\end{array}$ & $\begin{array}{c}\text { calcined } \\
\text { dolomite } \\
\text { powder }\end{array}$ & \\
\hline & \multicolumn{6}{|c|}{$[\mathrm{mg} / \mathrm{L}]$} \\
\hline As & 0.008 & 0.02 & 0.1 & 0.01 & 0.0003 & 5.0 \\
\hline $\mathrm{Cd}$ & 0.0002 & 0.0002 & 0.2 & 0.0002 & 0.000008 & 1.0 \\
\hline $\mathrm{Cr}$ & 0.0003 & 0.03 & 0.5 & 0.05 & 0.004 & 5.0 \\
\hline $\mathrm{Cu}$ & 0.004 & 0.0009 & 0.5 & 0.001 & 0.001 & - \\
\hline $\mathrm{Ni}$ & 0.01 & 0.02 & 0.5 & 0.01 & 0.04 & - \\
\hline $\mathrm{Pb}$ & 0.02 & 0.003 & 0.5 & 0.005 & 0.007 & 5.0 \\
\hline $\mathrm{Zn}$ & 0.004 & 0.005 & 2.0 & 0.008 & 0.02 & - \\
\hline
\end{tabular}

* Rozporzadzenie Ministra Środowiska z dnia 18 listopada 2014 r. w sprawie warunków, jakie należy spetnić przy wprowadzaniu ścieków do wód lub do ziemi, oraz w sprawie substancji szczególnie szkodliwych dla środowiska wodnego. Dz.U. 2014, poz. 1800.

“_" - not determined in the TCLP test. 
On the other hand, concrete is the most popular building material used in huge amounts. Nevertheless, studies of dolomite powder in usage as a filler in concrete production could be done by performing tests on fresh and hardened concrete samples, made with different proportions of powder added to the concrete mixture. These studies should also provide the answer to the question if production with dolomite dust powder as a filler would be comercially justified. Due to the chemical composition of the dolomite powder, consisting of more than 5\% wt., $\mathrm{CaO}$ and $\mathrm{MgO}$ (Małolepszy et al. 1994, Konik et al. 2007, Kurdowski 2010), the material cannot be considered as potential replacement for clinker in cement production, even though the studies on calcination were promising because of the mineral phases formed. On the other hand, while the procedure of $\mathrm{MgO}$ extraction from dolomite is normally used (Beruto et al. 2003, Bogahawatta et al. 2004), the $\mathrm{MgO}$ extraction experiment from dolomite powder could be investigated. According to results obtained by Rashad and Baioumy (2005), MgO recovery was increased by decreasing the particle size. Therefore, the tested material should be considered in environmental protection, where, in industrial application, large amounts of cleaning materials are needed. The purification of exhaust gases from contaminations such as $\mathrm{SO} x$ and $\mathrm{CO}_{2}$ on dolomite dust can be analysed. However dolomite might produce more $\mathrm{CO}_{2}$, so appropriate experiments are needed. In the case of the raw materials, the justified direction in which dolomite could be used is wet flue gas desulfurization (Yoshimi \& Kenichi 1969, Özyuğuran \& Ersoy-Meriçboyu 2012). On the other hand, the calcined material could be suitable for $\mathrm{CO}_{2}$ capture (Fang et al. 2009). However the important question remains if the costs of the calcination process of the raw material for gas capture are justified. The characteristics of the raw and calcined material are useful in planning the sorption research of metals in order to find its application for removal of heavy metals from wastewater. Additionally, it is not possible to use the powder in agriculture as a potential fertilizer, because the permissible $\mathrm{Pb}$ concentration in the material, defined as $600 \mathrm{ppm}$, is exceeded according to the Polish standard PNC87006-2:1996. This level was not exceeded for calcined dolomite powder.

After the analysis of the results, it can be concluded that the most promising dolomite powder utilization is connected with environmental protection. The chemical, mineralogical and textural properties point to the necessity for further research, with a primary focus on the sorption of metals from wastewater or $\mathrm{SO}_{2}$ from flue gas. Because of the high content of $\mathrm{Ca}$ and $\mathrm{Mg}$, the raw dolomite material should be examined for removal of heavy metals from aqueous solutions or as a material for wet flue gas desulfurization (taking into account small grain fractions). The calcination of the sample caused the carbonate minerals to change into oxide forms almost entirely.

\section{CONCLUSIONS}

The results of dolomite dust analysis showed that the raw material consists mainly of carbonate minerals, while the calcined material is mainly comprised of oxide minerals. The chemical composition comprises primarily calcium, magnesium and sili$\mathrm{ca}$, which indicates the presence and predominance of carbonate and silica minerals. Iron, aluminum and sulfur are present in similar, but much lower concentrations. Leaching tests for selected metals showed that the dolomite powder cannot be classified as hazardous waste, according to the TCLP test. The concentration of metals that can get into the environment does not exceed permissible values by Polish law. The calcination of the raw dolomite powder caused the formation of a practically non-porous material, with its surface area more than five times smaller than that of the raw material. Calcined material cannot be used as an additive in cement, due to the high content of calcia in the sample. Thus, basing on the current research, it can be stated that for the investigated dolomite powder, further detailed tests are necessary in order to define its proper application in heavy metal sorption from artificial wastewater or in $\mathrm{SO}_{2}$ and $\mathrm{CO}_{2}$ capture experiments from flue gases.

This research has been funded by AGH University of Science and Technology Statutory Research No. 11.11.140.199.

\section{REFERENCES}

Ahmaruzzaman M., 2011. Industrial wastes as low-cost potential adsorbents for the treatment of wastewater laden with heavy metals. Advances in Colloid and Interface Science, 166(1-2), 36-59. 
Alaibdo A.A., Elmoaty A. \& Auda E.M., 2014. Re-use of waste marble dust in the production of cement and concrete. Construction and Building Materials, 50, 28-41.

Aziz H.A., Adlan M.N. \& Ariffin K.S., 2008. Heavy metals $(\mathrm{Cd}, \mathrm{Pb}, \mathrm{Zn}, \mathrm{Ni}, \mathrm{Cu}$ and $\mathrm{Cr}(\mathrm{III})$ ) removal from water in Malaysia: Post treatment by high quality limestone. Bioresource Technology, 99, 1578-1583.

Bąk B., Radwanek-Bąk B. \& Wyszomirski P., 2011. Aktualny przegląd krajowych złóż dolomitów w aspekcie wykorzystania w przemyśle materiałów ogniotrwałych. Gospodarka Surowcami Mineralnymi - Mineral Resources Management, 27(1), 21-47.

Beruto D.T., Vecchiattini R. \& Giordani M., 2003. Solid products and rate-limiting step in the thermal half decomposition of natural dolomite in a $\mathrm{CO}_{2}(\mathrm{~g})$ atmosphere. Thermochimica Acta, 405, 183-194.

Bilgin N., Yeprem H.A., Arslan S., Bilgin A., Günay E. \& Marşoglu M., 2012. Use of waste marble powder in brick industry. Construction and Building Materials, 29, 449457.

Bogahawatta V.T.L., Abdul-Jaleel A. \& Behbehani M., 2004. The heat treatment and particle size effects in the thermal decomposition of dolomite for separation of constituents. Mineral Processing and Extractive Metallurgy, doi: 10.1179/037195504225005750.

de Boer J.H., 1958. [in:] Everett D.H. \& Stone F.S. (eds), The structure and Properties of Porous Materials, Butterworth, London, 68.

Brunauer S., Emmett P.H. \& Teller E., 1938. Adsorption of gases in multimolecular layers. Journal of the American Chemical Society, 60(2), 309-319.

Chen C.G., Sun C.J., Gau S.H., Wua C.W. \& Chen Y.L., 2013. The effects of the mechanical-chemical stabilization process for municipal solid waste incinerator fly ash on the chemical reactions in cement paste. Waste Management, 33, 858-865.

Dehghani A. \& Bridjanian H., 2010. Flue gas desulfurization methods to conserve the environment. Petroleum \& Coal, 52(4), 220-226.

Dell'Orso M., Mangialardi T., Paolini A.E. \& Piga L., 2012. Evaluation of the leachability of heavy metals from cement-based materials. Journal of Hazardous Materials, 227-228, 1-8.

Disfani M.M., Arulrajah A., Bo M.W. \& Hankour R., 2011. Recycled crushed glass in work applications. Waste Management, 31, 2341-2351.

Engelsen C.J., Wibetoe G., van der Sloot H.A., Lund W. \& Petkovic G., 2012. Field site leaching from recycled concrete aggregates applied as sub-base material in road construction. Science of the Total Environment, 427-428, $86-97$.

Fang F., Li Z.S. \& Cai N.S., 2009. $\mathrm{CO}_{2}$ capture from flue gases using a fluidized bed reactor with limestone. Korean Journal of Chemical Engineering, 26(5), 1414-1421.

Galvín A.P., Ayuso J., Agrela F., Barbudo A. \& Jiménez J.R., 2013. Analysis of leaching procedures for environmental risk assessment of recycled aggregate use in unpaved roads. Construction and Building Materials, 40, 1207-1214.

Gregg S.J. \& Sing K.S.W., 1982. Adsorption, Surface Area and Porosity. Academic Press, London.
Gruszecka-Kosowska A. \& Mikoda B., 2015. Commercial utilization of mineral waste: review of analysis methods determining its compliance with environmental laws. Geology, Geophysics \& Environment, 41(3), 263-274, doi: 10.7494/geol.2015.41.3.263.

Harris D.L. \& Lottermoser B.G., 2006. Evaluation of phosphate fertilizers for ameliorating acid mine waste. Applied Geochemistry, 21, 1216-1225.

Helios-Rybicka E., Jarosz-Krzemińska E. \& Gawlicki M., 2013. Zastosowanie zneutralizowanych, potrawiennych materiałów odpadowych $w$ postaci szlamów uzyskanych w wyniku trawienia powierzchni metalicznych. PL 216497 B1.

Hewlett P., 1998. Lea's Chemistry of Cement and Concrete. Arnold, London.

Kinuthia J.M. \& Nidzam R.M., 2011. Towards zero industrial waste: Utilisation of brick dust waste in sustainable construction. Waste Management, 31, 1867-1878.

Konik Z., Małolepszy J., Roszczynialski W. \& Stok A., 2007. Production of expansive additive to portland cement. Journal of the European Ceramic Society, 27, 605-609.

Kozłowski S., 1986. Surowce skalne Polski. Wydawnictwa Geologiczne, Warszawa.

Kurdowski W., 2010. Chemia cementu $i$ betonu. Stowarzyszenie Producentów Cementu, Kraków, Wydawnictwo Naukowe PWN, Warszawa.

Lewandowska A., 1991. Minerals of the zone of altered Devonian dolomites from Dubie area near Kraków (Southern Poland). Mineralogia Polonica, 22(2), 20-38.

Macías F., Caraballo M.A. \& Nieto J.M., 2012. Environmental assessment and management of metal-rich wastes generated in acid mine drainage passive remediation systems. Journal of Hazardous Materials, 229-30, 107-114.

Mahmoud M.E., Hafez O.F., Alrefaay A. \& Osman M.M., 2010. Performance evaluation of hybrid inorganic/organic adsorbents in removal and preconcentration of heavy metals from drinking and industrial waste water. Desalination 253, 9-15.

Małolepszy J., Gawlicki M., Brylicki W., Deja J., Żurawski S., Szczepaniak K., Mrozowicz J. \& Rutkowski J., 1994. Zestaw surowcowy do wytwarzania klinkieru portlandzkiego. PL 162748 B1.

Mangwandi C., Tao, L.J., Albadarin A.B. \& Walker G.M., 2013. Alternative method for producing organic fertiliser from anaerobic digestion liquor and limestone powder: high shear wet granulation. Powder Technology, 233, 245-254.

Merrikhpour H. \& Jalali J., 2012. Waste calcite sludge as an adsorbent for the removal of cadmium, copper, lead and zinc from aqueous solutions. Clean Technologies and Environmental Policy, 14, 845-855.

Ney R. (red. nauk.), 2000. Surowce skalne: surowce weglanowe. Series: Surowce Mineralne Polski, Wyd. Instytutu GSMiE PAN, Kraków.

Özyuğuran A. \& Ersoy-Meriçboyu A., 2012. Using hydrated lime and dolomite for sulfur dioxide removal from flue gases. Chemical Engineering Transactions, 29, 1051-1056.

Park J.Y. \& Chertow M.R., 2014. Establishing and testing the "reuse potential" indicator for managing wastes as resources. Journal of Environmental Management, 137, $45-53$. 
Pérez-López R., Castillo J., Quispe D. \& Nieto J.M., 2010. Neutralization of acid mine drainage using the final product from $\mathrm{CO}_{2}$ emissions capture with alkaline paper mill waste. Journal of Hazardous Materials, 177, 762-772.

Peukert S., 2000. Cementy powszechnego użytku i specjalne: podstawy produkcji, właściwości i zastosowanie. Stowarzyszenie Producentów Cementu, Kraków.

PN-C87006-2:1996 Nawozy sztuczne wapniowo-magnezowe - Podział, oznaczenie i wymagania.

PN-EN 12457-1:2006 Charakteryzowanie odpadów - Wymywanie - Badanie zgodności w odniesieniu do wymywania ziarnistych materiałów odpadowych i osadów - Część 1: Jednostopniowe badanie porcjowe przy stosunku cieczy do fazy stałej $2 \mathrm{l} / \mathrm{kg}$ w przypadku materiałów o wysokiej zawartości fazy stałej i wielkości czastek poniżej $4 \mathrm{~mm}$ (bez redukcji lub z redukcją wielkości).

Poon C.S. \& Chan D., 2006. Feasible use of recycled concrete aggregates and crushed clay brick as unbound road subbase. Construction and Building Materials, 20, 578-585.

Rashad M.M. \& Baioumy H.M., 2005. Chemical processing of dolomite associated with the phosphorites for production of magnesium sulfate heptahydrate. The European Journal of Mineral Processing and Environmental Protection, 5(2), 174-183.

Romero D., James J., Mora R. \& Hays C.D., 2013. Study on the mechanical and environmental properties of concrete containing cathode ray tube glass aggregate. Waste Management, 33, 1659-1666.

Rozporzadzenie Ministra Środowiska $z$ dnia 18 listopada 2014 r. w sprawie warunków, jakie należy spetnić przy wprowadzaniu ścieków do wód lub do ziemi, oraz w sprawie substancji szczególnie szkodliwych dla środowiska wodnego. Dz.U. 2014, poz. 1800 [Journal of Laws from 2014, item 1800].

Said A., Mattila H.P., Järvinen M. \& Zevenhoven R., 2013. Production of precipitated calcium carbonate (PCC) from steelmaking slag for fixation of $\mathrm{CO}_{2}$. Applied Ener$g y, 112,765-771$.

Sarbak Z., 2005. Metody instrumentalne $w$ badaniach adsorbentów i katalizatorów. Chemia - Uniwersytet im. Adama Mickiewicza w Poznaniu, 75, Wydawnictwo Naukowe Uniwersytetu im. Adama Mickiewicza, Poznań.
Skarżyńska K.M., 1995. Reuse of coal mining wastes in civil engineering. Part 2: Utilization of minestone. Waste Management, 15(2), 83-126.

Tozsin G., Arol A.I., Oztas T. \& Kalkan E., 2014. Using marble wastes as a soil amendment for acidic soil neutralization. Journal of Environmental Management, 133, 374-377.

Trypuć M. \& Białowicz K., 2011. $\mathrm{CaCO}_{3}$ production using liquid waste from Solvay method. Journal of Cleaner Production, 19, 751-756.

Uliasz-Bocheńczyk A., Mokrzycki E., Piotrowski Z. \& Pomykała R., 2009. Estimation of $\mathrm{CO}_{2}$ sequestration potential via mineral carbonation in fly ash from lignite combustion in Poland. Energy Procedia, 1, 4873-4879.

US EPA, 1992. SW-846 Test Method 1311: Toxicity Characteristic Leaching Procedure, part of Test Methods for Evaluating Solid Waste, Physical/Chemical Methods. Rev. 0, Office of Solid Waste, Washington, DC.

US EPA, 2014. RCRA Orientation Manual 2014. Resource Conservation and Recovery Act. Office of Resource Conservation and Recovery Program Management. Communications and Analysis Office, Washington, DC.

Wang Y.H., Lin S.H. \& Juang R.S., 2003. Removal of heavy metal ions from aqueous solutions using various lowcost adsorbents. Journal of Hazardous Materials, 102(2-3), 291-302.

Wdowin M. \& Gruszecka A.M., 2012. Charakterystyka mineralogiczno-chemiczna i teksturalna odpadów poflotacyjnych z przemysłu $\mathrm{Zn}-\mathrm{Pb}$ pod kątem dalszych rozważań wykorzystania ich jako sorbentów. Gospodarka Surowcami Mineralnymi - Mineral Resources Management, 28(3), 55-69.

Xing S., Zhao M. \& Ma Z., 2011. Removal of heavy metal ions from aqueous solution using red loess as an adsorbent. Journal of Environmental Science, 23, 1497-1502.

Yoshimi I. \& Kenichi O., 1969. Method for removing sulfur dioxide from flue gases of a combustion furnace. US 3481289 A.

Zhang J., Liu J., Nie Y. \& Jin Y., 2008. Comparison of the fixation of heavy metals in raw material, clinker and mortar using a BCR sequential extraction procedure and NEN7341 test. Cement and Concrete Research, 38, 675-680. 